\title{
Fennougristiikan historiaa Virittäjän valossa ${ }^{1}$
}

\author{
Jussi Ylikoski
}

\section{Johdanto}

125 vuotta täyttävä Virittäjä kuvataan sen verkkosivuilla suomen kielen ja sen opetuksen tutkimusta esitteleväksi tieteelliseksi aikakauslehdeksi. Virittäjä on kuitenkin aina ollut myös paljon muuta. Suomen kielen tutkimus on suomalais-ugrilaisen kielen tutkimusta, vaikka Suomessa siitä on kansalliskielen aseman ansiosta kehittynyt niin vahva kielentutkimuksen alalaji, että niin sanottu fennougristiikka koetaan meillä yleensä pikemminkin suomen sukukielten ja niiden muinaisten kielikontaktien tutkimukseksi. Tällaisesta fennougristiikastakaan Virittäjä ei kuitenkaan ole koskaan irrottautunut; systemaattisimman tapaustutkimuksen tarjoavat tässä juhlanumerossa Sampsa Holopainen, Santeri Junttila ja Petri Kallio (2021) esitellessään lainasanatutkimuksen historiaa Virittäjän valossa aineistosta ei ole ollut pulaa.

Tässä kirjoituksessa tarkastelen itsekin Virittäjän historiaa fennougristin silmin. Artikkelini on luonteeltaan katsauksenomainen, kun taloudellisuussyistä rajaan katseeni ulkopuolelle muun muassa suuren osan edellä mainitusta etymologisesta tutkimuksesta sekä siihen liittyvästä äännehistoriallisesta tutkimuksesta. Samoin rajaan tarkastelun ulkopuolelle merkittävän osan sukukieltemme tutkimusta: Niin fennougristista kuin karjalan, vepsän ja kymmenisen muun lähisukukielemme tutkimus onkin, Virittäjän historiassa itämerensuomalaisten kielten tutkimus on pitkään ollut fennististä perustutkimusta, suomen kielen tutkimusta sanan "yhteissuomalaisessa" merkityksessä; vielä toisen maailmansodan aikoihin Virittäjässäkin oli aivan luonnollista keskustella siitä, onko karjala itsenäinen kielensä vai vain osa suomea, johon vepsääkin tietoisesti lähennettiin (esim. Kettunen 1940; Peltola 1946; Airila 1946). Virittäjän historiaan on mahtunut myös muun muassa Paul Aristen vironkielisiä kirjoituksia vatjasta, liivistä ja etelävirosta, mutta tällaiset suomen läheiset sisaret suljen tässä kirjoituksessa entisaikojen fennistien tontille.

\footnotetext{
${ }^{1}$ Viimeinen taittamaton käsikirjoitusversio artikkelista, joka on ilmestynyt Virittäjässä 125 s. 476-498. https://doi.org/10.23982/vir.97473
} 
Ja edelleen: rajaan fennougristiikan tarkastelun kielentutkimukseen, jonka ulkopuolelle jäävät esimerkiksi mansien kohtalolaulujen sekä mordvalaisten ja marien asumusten ja kotipalvonnan tutkimus, jota Virittäjä niin ikään on lukijoilleen historiansa aikana tarjoillut. On silti hyvä tiedostaa, että alkuaikojen Virittäjässä julkaistiin niinkin kaukaista uralilaisaltailaisten kielten ja kansojen tutkimusta kuin G. J. Ramstedtin (1900) artikkeli "Tsagan sara, mongolilainen juhla”. Etenkin noihin aikoihin oli hieman epäselvää, mitkä pohjoisen Euraasian kansoista todella voitiin katsoa suomalaisten sukukansoihin, ja keskustelua on jatkettu pitkään Virittäjässäkin (esim. Joki 1965; Janhunen 1984).

Edellä mainittujen rajausten vastapainoksi kutsun fennougristiikaksi nykyaikaiseen tapaan koko uralistiikkaa eli uralilaisten kielten tutkimusta tekemättä eroa kielikunnan niin sanotun suomalais-ugrilaisen ja samojedilaisen haaran välillä. ${ }^{2}$ Vaikka Virittäjän alkuvuosina samojedin ja suomen sukulaisuutta ei vielä ollut tyhjentävästi osoitettu, monien nykyasiantuntijoiden silmissä samojedikielet eivät enää näytä taksonomisesti sen kaukaisemmilta kuin muutkaan etäsukukielet. Kielihistorian lisäksi käsitykseni fennougristiikasta kattaa myös kielikuntamme nykyisyyden. Vaikka Janhusen (1996) mukaan yksittäisten uralilaisten kielten synkronista tutkimusta ei tulisi lukea varsinaisen fennougristiikan piiriin, itse katson tällaisillakin aloilla olevan oma paikkansa fennougristiikassa laajasti ymmärrettynä - tarkka rajanveto olisi joka tapauksessa mahdoton tehtävä.

Näin lyhyt kirjoitus ei voi olla millään tapaa systemaattinen analyysi Virittäjän ja fennougristiikan suhteista, mutta aiheen yleisen esittelyn lisäksi toivon osaavani nostaa esille myös aiemmin vähemmälle huomiolle jääneitä tutkimusperinteen yleispiirteitä ja erityisesti Virittäjän historiassa tärkeitä yksittäisiä fennougristeja. Luvussa 2 luon silmäyksen niin Virittäjän kuin muunkin suomalaisen fennougristiikan historian tutkimukseen sekä esitän lyhyen tiivistelmän fennougristiikan olemuksesta. Virittäjän ja fennougristien symbioosia tarkastellessa esille nousee useankinlaisia ilmiöitä. Prototyyppisintä fennougristiikkaa edustavat konkreettiset pyrkimykset suomen ja sen sukukielten menneisyyden

\footnotetext{
${ }^{2}$ Tässä kirjoituksessa puhun yleensä suomalais-ugrilaisia kieliä tutkivasta fennougristiikasta, vaikka yhtä hyvin voisin puhua yksiselitteisemmin uralilaisia kieliä tutkivasta uralistiikasta; tässä valittu perinteinen linja sopii hyvin erityisesti Virittäjän historian tarkasteluun.
} 
valaisemiseksi: toisiinsa kietoutuneet etymologia ja äännehistoria sekä niiden kehyksiksi hahmotellut kantakielet eri vaiheineen ja kontaktikielineen (luku 3).

Fennougristiikan kovan ytimen ulkopuolella ovat kuitenkin suuremmat kehykset: pohdinnat siitä, miksi ja miten tällaista tutkimusta harjoitetaan, ja halu kertoa fennougristisen tutkimuksen tuloksista myös suurelle yleisölle (luku 4). Erityisesti Suomi ja täällä etenkin Virittäjä ovat ympäristöjä, joissa fennougristit ovat kerta toisensa jälkeen pohtineet ja esitelleet olemassaolonsa tarkoitusta. Vaikka näissä ja muidenkin puheissa on usein korostunut kielihistorian merkitys, fennougristit ovat aina harjoittaneet myös synkronista kielentutkimusta, mikä toki onkin kielikunnan diakronisen tutkimuksen edellytys. Suomen sukukielten nykyisyyteen ja tulevaisuuteen eli kielten uhanalaisuuteen ja vähemmistökielten puhujien oikeuksiin on kiinnitetty huomiota jo kauan, jo ennen Virittäjän ensimmäisiä albumeja (luku 5). Tämä artikkeli keskittyy lähinnä Virittäjän ensimmäiselle vuosisadalle, mutta 2020-luvulle tultaessa fennougristiikka ja sen ilmenemismuodot Virittäjässä ovat muuttuneet lehden yleisilmeeseen verrattuna suhteellisen vähän (luku 6). Virittäjä on yhä fennougristinen julkaisu ja luultavasti pysyy sellaisena tulevaisuudessakin. ${ }^{3}$

\section{Taustaa}

Perusteellisista historiateoksista huolimatta Virittäjän ja fennougristiikan valokeilat ovat kohdanneet toisensa harvoin. Fennougristit ovat kirjoittaneet paljon Virittäjässä, mutta eivät Virittäjästä; Virittäjän historiaa tarkasteltaessa on kirjoitettu paljon suomesta, mutta niukasti sen sukukielistä (luku 2.1). Fennougristiikkaa tieteenä on määritelty moneen otteeseen, ja vaikka fennougristiikan syvin olemus ja itseymmärrys eivät ole sanottavasti muuttuneet koko Virittäjän historian aikana, eräät pääasiat on paikallaan kerrata (luku 2.2).

\subsection{Virittäjän ja sen sisarjulkaisujen historiaa}

Kotikielen Seuran (1876) lähin sisarseura Suomalais-Ugrilainen Seura (1883) perustettiin samana vuonna, jona ensimmäinen Virittäjä-niminen albumi ilmestyi. Nykymuotoinen säännöllisesti ilmestyvä Virittäjä syntyi vuonna 1897. Jo tätä ennen sai alkunsa hieman

\footnotetext{
${ }^{3}$ Kiitän Virittäjän toimitusta ja nimettömiä arvioijia sekä monia kollegoitani artikkelini käsikirjoitusversioiden kommentoinnista. Kirjoituksen lopullisesta sisällöstä vastaan luonnollisesti itse.
} 
satunnaisemmin ilmestyvä Suomalais-Ugrilaisen Seuran Aikakauskirja (1886), joka sai myöhemmin seurakseen Suomalais-Ugrilaisen Seuran piirissä toimitetun Finnisch-Ugrische Forschungenin (1901). Kotikielen Seuran historiaa ovat esitelleet laajasti Paunonen (1976) ja Juusela (2006), Suomalais-Ugrilaista Seuraa puolestaan Korhonen ym. (1983), Salminen (2008) sekä Kokkonen ja Kurvinen (2010).

1800-luvun lopulla fennistiikka oli vasta alkanut irtautumaan fennougristiikasta virallisimmaksi virstanpylvääksi katsotaan alan ainoan professuurin jakaminen kahtia vuonna 1892 - ja samat henkilöt vaikuttivat usein molemmissa seuroissa ja niiden julkaisuissa sekä moniaalla muuallakin. August Ahlqvist, jonka usein muistellaan moittineen Virittäjäksi ristityn julkaisun nimeä (esim. Paunonen 1976: 398; Juusela 2006: 25), vastusti myöhemmin Suomalais-Ugrilaisen Seuran 1. varaesimiehenä esimies Otto Donnerin seuran aikakauskirjalle esittämää nimiehdotusta Altai. "Näin seuran aikakauskirja sai nykyisen pitkänpuoleisen ja ikävänlaisen nimensä”, pahoitteli E. N. Setälä (1929: 130) seuran 40vuotisesitelmässään 2.12.1923. Astetta kansainvälisemmän Finnisch-Ugrische Forschungenin perustivat Setälä ja Kaarle Krohn pian sen jälkeen kun molemmat olivat olleet käynnistämässä Virittäjää. Noilta ajoilta periytyy myös yhä voimassa oleva yhteistyö, jossa Suomalais-Ugrilaisen Seuran hallinnoimien August Ahlqvistin, Yrjö Wichmannin, Kai Donnerin ja Artturi Kanniston rahastojen tuotosta vuosittain jaettavat apurahat ja palkinnot julkistetaan Kotikielen Seuran vuosikokouksessa (Paunonen 1976: 327).

Vaikka Suomalais-Ugrilainen Seura julkaisee kahta omaa aikakauskirjaa sekä muita sarjoja, suomalaisilla fennougristeilla on aina ollut tiiviit yhteydet myös Virittäjään. Seuraavissa luvuissa tarkastellaan nimenomaan tässä lehdessä julkaistua fennougristiikkaa - sitä, mitä Virittäjä on merkinnyt fennougristeille ja mitä fennougristiikka Virittäjälle. Tätä yhdistelmää ei ole aiemmin varsinaisesti kuvattu. Esimerkiksi Salminen (2008) kuvaa SuomalaisUgrilaisen Seuran ja samalla koko suomalaisen fennougristiikan historian jokseenkin ulkopuolisena aate- ja tieteenhistorian tutkijana; tähän perusteelliseen teokseen viitaten rajaan oman esitykseni ulkopuolelle myös suomalaista fennougristiikkaa ohjanneiden ideologisten ja poliittisten vaikuttimien tarkastelun. Muissakin fennougristiikkaan keskittyvissä esityksissä käsitellään ymmärrettävästi yleensä lähinnä Suomalais-Ugrilaisen Seuran omaa julkaisutoimintaa (esim. Kannisto 1933; Ravila 1933b: 59-66; Aalto 1958: 24-39). 
Juusela (2006) puolestaan tarkastelee Virittäjän reilun satavuotista historiaa fennistin silmin ja toteaa (mts. 10), että teoksessa näkyvät tekijän omat kiinnostuksen kohteet. Suomen sukukielten tutkimus mainitaan muun muassa silloin, kun Virittäjässä vallinneet painopisteet ovat siirtyneet etymologian ja äännehistorian alalta uusiin suuntiin (mts. 100-102). Erityistä huomiota fennougristit ja heidän luonteenpiirteensä saavat luvussa "Polemiikkia ja kielitieteellisiä väittelyjä” (mts. 150-174). Kuvatuista erimielisyyksistä on muutenkin tullut yksi kielitieteellisen historiankirjoituksemme suosikkiaiheista; usein korostetaan vastakkainasettelua, jonka osapuoliksi kuvataan diakronisemmin orientoituneet konservatiivit ja synkroniaan keskittyneet yleislingvistiset uudistajat (esim. Hakulinen 1993; Karlsson 1997; Itkonen 1999: 47-61; Häkkinen 2010). Toisaalta Juusela esittelee eräitä etymologian ja muun historiallisen kielentutkimuksen saavutuksia suomalaisen kielitieteen etulinjassa syntyneinä klassikkoina (mts. 175-184).

Vaikka Juusela (2006) kuvaa perusteellisesti sen fennistisen ympäristön, jossa Virittäjää on yli sadan vuoden ajan toimitettu, kirjoitettu ja luettu, teoksesta ei välity selvästi se, kuinka monipuolista myös muiden uralilaisten kielten tutkimus Virittäjässä on aina ollut. Historian loppulehdillä (mts. 208-212) korostetaan satavuotiaan Virittäjän nostaneen 1990-luvun lopulta lähtien esille myös vähemmistökielet sekä kielten uhanalaisuuden ja elvyttämisen problematiikan, mutta nämä aiheet esitetään ikään kuin uusina avauksina lehden historiassa. Juuselan teoksen arvioinut Korppi-Tommola (2011: 119) onkin saanut koko Virittäjän historiasta käsityksen, että Kotikielen Seuran lehti keskittyi ensimmäisen vuosisatansa ajan vain yhden kotikielen eli suomen tutkimukseen "aina 1990-luvulle asti, kunnes päätoimittaja Lea Laitinen laajensi käsitettä, ja Virittäjässä alettiin käsitellä myös saamen kieltä”.

Todellisuudessa esimerkiksi saamelaiskielten osuus Virittäjän sivuilla on ajan mittaan vähentynyt, sillä lehden historian alkupuoliskolla niistä puhuttiin vähintään joka toisessa niteessä. Enempien väärinkäsitysten välttämiseksi tarkastelen ja esittelen tässä artikkelissa sitä, kuinka saamea ja muita sukukieliämme on käsitelty Virittäjässä yhtäjaksoisesti vuodesta 1897 alkaen. 125-vuotias Virittäjä on julkaissut kymmenillä tuhansilla sivuillaan tuhansia kirjoituksia, joista sadat käsittelevät suomen sukukieliä. 


\subsection{Fennougristiikan olemuksesta}

Tarkasteluni taustaksi on paikallaan esittää muutama täsmentävä huomautus aiheeni toisen puolen eli fennougristiikan olemuksesta: sen olemassaolon syistä, päätehtävistä ja päätavoitteista. Fennougristiikka eli uralistiikka on suomalais-ugrilaisten eli uralilaisten kielten tutkimusta. Koska juuri näitä 40-50 kieltä yhdistää määritelmällisesti ja tosiasiallisesti vain niiden yhteiseksi todistettu alkuperä eli kyse on eksklusiivisesti yhdestä yhteisestä kantakielestä polveutuvista sukulaiskielistä, fennougristiikan ydintehtävänä ja päätavoitteena on parivuosisataisen historiansa ajan ollut näiden sukulaiskielten sukulaisuussuhteiden selvittäminen. Jos suomalais-ugrilaiset kielet eivät kuuluisi geneettisesti yhteen ja niin selvästi eroaisi kaikista muista tunnetuista kielistä, suomalais-ugrilaista kielentutkimusta ei oikeastaan voisi olla olemassa.

Diakronisen fennougristiikan ja muun historiallis-vertailevan kielentutkimuksen keskeisimmät alalajit ovat toisiinsa erottamattomasti liittyvät äännehistoriallinen ja etymologinen tutkimus. Keskeistä on myös yhteisten kieliopillisten elementtien jäljittäminen, mutta koska sanoja on tuhansin verroin enemmän kuin kieliopillisia morfeemeja - ja edellisten kehityskulut ovat säännöllisempiä ja siksi helpommin jäljitettävämpiä historiallisen fennougristiikan ytimessä ovat käytännössä aina olleet ennen kaikkea äännehistoria ja etymologia. Merkitystä on myös syntaksin tutkimuksella, mutta yleensä konkreettisia jälkiä jättämättömien sanajärjestysten tutkimus soveltuu lähtökohtaisesti paljon huonommin muinaisimpien kantakielten rekonstruoimiseen. Äännehistorian ja etymologian roolia on tukenut sekin, että niiden luonnontieteellisen eksakti metodologia kehittyi pitkälle jo 1800-luvulla, ja toisaalta sanaston kehitys on vahvasti kytköksissä myös kielenulkoiseen kulttuuri- ja sosiohistoriaan.

Juuri kantakielten rekonstruoiminen on siis suomalais-ugrilaiseen sukututkimukseen pohjautuvan tieteen ydintehtäviä. Kyse ei ole vain koko kielikunnalle yhteisen kantakielen rekonstruoimisesta vaan kaikkien rekonstruoitavissa olevien kantakielten jäljittämisestä siitä, millaisiin erilaisiin välikantakieliin ja niistä muodostuneisiin myöhempiin kielihaaroihin kielikunta voidaan jakaa. Tällöin selvitellään myös kielikunnan sisäistä taksonomiaa ja sen ohella luonnollisesti sitä, mistä, miten ja milloin kukin kielihaara ja -ryhmä on levinnyt uusille alueille. Voi sanoa, että koko tieteenalan pohjimmainen tehtävä on periaatteessa selvittää, millainen oli kielikunnan yhteinen kantakieli, missä ja milloin sitä puhuttiin, sekä 
miten se jakautui nykyisiksi kieliksi. Näiden kysymysten ratkaisemisen yhteiskunnalliset motiivit ovat tietysti esimerkiksi Suomessa olleet myös kansallispoliittisia (Salminen 2008).

Näiden suunnattoman suurten kysymysten pohtiminen ja ratkaiseminen ei tietenkään ole mahdollista ilman kaikkea synkronisen kielentutkimuksen keinoin saatavissa olevaa tietoa kymmenten kielten nykyisyydestä, ja yhtä vähän on mahdollista sulkea näköpiirin ulkopuolelle kielikuntamme eriaikaisten naapurikielten ja -kielikuntien tutkimusta. Ydinkysymysten määrittelyssä ei ole kyse mieltymyksistä tai arvoasetelmista, vaan siitä, että suomalais-ugrilaisuus on nimenomaan kielisukulaisuutta ja näin ollen suomalais-ugrilaisen kieliperheen tutkimus on pohjimmiltaan kielitieteellistä sukututkimusta. Tästä ovat kaikkina aikoina olleet yksimielisiä diakronisen kielitieteen edustajien rinnalla myös itse synkronisemmin, lauseopillisemmin ja yleislingvistisemmin suuntautuneet fennougristit (ks. esim. Nielsen 1912; Toivonen 1934; Ravila 1949; Alhoniemi 1972; 1996; Janhunen 1996; 2007; Grünthal \& Laakso 2001).

Fennougristiikkaan on siis kuitenkin aina välttämättömänä kuulunut myös yksittäisten kielten synkroninen kuvaaminen ja kaikkinainen dokumentointi. Tätä kaiken diakronisenkin kielentutkimuksen materiaaliaittaa ovat suomalaisetkin fennougristit määrätietoisesti kartuttaneet aina A. J. Sjögrenistä, Elias Lönnrotista, M. A. Castrénista ja August Ahlqvistista alkaen jo ennen kuin myöhempi diakroninen tutkimus vakiinnutti nykykäsityksen kielikuntamme rajoista. Synkroniseen fennougristiikkaan palaan tarkemmin kirjoituksen loppupuolella.

\section{Huutomerkkejä ja kantakieliä}

Kettusen vastaväite on hänelle tyypillinen: lapissa »monikon genetiivissä $n$ :ää muka ei olisi koskaan ollutkaan!» Olisi sopinut lisätä huutomerkkejä enemmänkin, jos kerran muuta perustelua ja pontta ei mielipiteensä tueksi kykene esittämään. (Itkonen 1957b: 435)

Kuten edellä on todettu, historiallisen fennougristiikan ytimeen eli etymologiaan ja siihen liittyvään äännehistoriaan keskittyy tässä niteessä Holopaisen ym. (2021) katsaus lainasanatutkimukseen. Äänneoppi liittyy kuitenkin erottamattomasti myös muoto-oppiin. 
1900-luvun merkittävimmäksi fennougristiksi katsottava akateemikko Erkki Itkonen julkaisi vuonna 1957 kirjoituksen "Suomalais-ugrilaisen kantakielen äänne- ja muotorakenteesta" (Itkonen 1957a), joka pohjautui samana vuonna pidettyyn virkaanastujaisesitelmään. Tämä tiivis kirjoitus on kansainvälisestikin viitatuimpia esityksiä siitä, mitä kielikuntamme varhaisvaiheista oli Virittäjän tähänastisen historian puolivälissä mahdollista tietää.

Itkosen kirjoitus kirvoitti kuitenkin kirpeän keskustelun tuoreen professorin ja tätä yli 30 vuotta vanhemman Lauri Kettusen välillä. Itämerensuomeen erikoistunut Kettunen oli jo vuosikymmeniä nostanut ja nostattanut monenlaista polemiikkia etenkin fennistien keskuudessa (Juusela 2006: 81-94). Kettunen (1957) otsikoi ensin tiiviin kymmensivuisen vastineensa sanoin "Problemaattista kantakielen genetiivissä ja paljossa muussa". Tätä seurasivat Itkosen vastine, vielä yksi Kettusen vastine ja lopuksi keskustelun päättäneet "Loppusanat prof. Kettuselle" (Itkonen 1957b), jotka olivat Itkosen kirjoitukseksi poikkeuksellisen suorasukaista tekstiä. Tällainen diskurssi on luonnollisesti historiankirjoittajien herkkua, ja valitettavan usein kielitieteen historiassakin huomio on mennyt enemmän suurten persoonallisuuksien kuvaamiseen. Kuten Häkkinen (2010: 586) huomauttaa, henkilöihin menevä kirjoittelu antaa vääristyneen kuvan tieteen todellisesta sisällöstä ja sen tekemisen pohjimmaisista syistä: ”Oman egon pönkittämiseen ja muiden kyykyttämiseen löytyy paljon tehokkaampiakin keinoja kuin äännehistorian tutkiminen”. Niin Itkonen kuin Kettunen edistivät tiedettä parhaansa mukaan. ${ }^{4}$

Monipuolisemman kuvan Virittäjän ja fennougristiikan arkisesta aherruksesta saa, jos poleemisimpien sanankäyttäjien lisäksi tarkastellaan myös esimerkiksi Yrjö Henrik Toivosen (1890-1956) kaltaisia tutkijoita. Suomalais-ugrilaisen kielentutkimuksen professori, akateemikko Toivonen julkaisi vuosina 1916-1956 Virittäjässä kaikkiaan 133 etymologista sana-artikkelia lähinnä suomen kielen sanoista. Näiden rinnalla, yli kolmenkymmenen vuoden ajan, Finnisch-Ugrische Forschungenissa ilmestyi aihepiiriltään vastaava mutta

\footnotetext{
${ }^{4}$ Saamen monikon genetiivin tunnukseen ei tiettävästi ole rekonstruoitu $n$-ainesta ennen Kettusta (1957) eikä hänen jälkeensä. Vaikka Kettunen oli laaja-alainen itämerensuomen tutkija ja alan ensimmäisten professuurien haltija sekä Tartossa että Helsingissä, hänen Virittäjän-tuotannossaan on havaittavissa jopa suoranaista hyökkäävyyttä etäsukukielten tutkimusta kohtaan. Muiden puhuessa fennougristeista Kettunen puhui 1920luvulta 1940-luvulle omintakeisesti ja selvästi pilkalliseen sävyyn "ugristeista": "Sanokoot ugristit mitä tahansa - -" (Kettunen 1938: 374), "- - selittäkööt sitten ugristit omat probleeminsa miten tahtovat - -" (Kettunen 1939: 162) jne. Keskenään "ugristit" eivät ole samalla tavalla kiukutelleet.
} 
fennougristisempi, 189-osaiseksi kasvanut kirjoitussarja. Näihin kätkeytyy valtava määrä kieli- ja kulttuurihistoriallista perustutkimusta, jonka tuloksista osa on vanhentunut ja osa yhä voimissaan, usein tietysti myöhempien tutkijoiden jalostamina - enimmäkseen Toivosen itsensä aloittaman Suomen kielen etymologisen sanakirjan ja sen perillisten muodossa. Toivosen kuoltua Ravila muisteli tätä seuraavasti:

Tuskinpa voi löytää hänen elämänvaiheistaan mitään, mikä osoittaisi edes niiden valtavien historiallisten tapahtumien, jotka osuivat hänen parhaisiin nuoruuden ja miehuuden vuosiinsa, saaneen hänet horjahtamaan pois varsinaisen elämäntehtävän suorittamisesta. Työkammio, yliopisto ja tieteelliset seurat muodostivat sen piirin, jonka rajoja hän ei juuri milloinkaan ylittänyt. (Ravila 1958: 53)

Etymologisen tutkimuksen yksittäiset askelet ovat johtaneet laajempiin käsityksiin siitä, millaista sanastoa erilaisiin kantakieliin voidaan rekonstruoida ja mitä on saatu muualta. Kantakieliä ei ole ainoastaan rekonstruoitu, vaan niitä on pyritty tietysti myös ajoittamaan ja paikantamaan. Esimerkiksi Toivosen (1953) laaja ja monipuolinen "Suomalais-ugrilaisesta alkukodista" lujitti pitkiksi ajoiksi kuuluisan Volgan mutkan aseman kantakielen kotipaikkana; artikkeli otti samalla kantaa kielitieteen mahdollisuuksiin selvittää kaukaisempia sukulaissuhteita. Toivosen pohdintoja kantakielten kronologiasta päivitti parinkymmenen vuoden kuluttua Mikko Korhonen (1976) ja kolme vuosikymmentä tämän jälkeen edelleen Petri Kallio (2006), molemmat Virittäjässä.

Laaja-alaisimmat Virittäjässä esitetyt fennougristiset synteesit ovat usein olleet taustaltaan yleistajuistettuja virkaanastujaisesitelmiä (esim. Joki 1965; Bartens 1981), mutta erityisen tuottelias ja syvällinen pohdiskelija oli Paavo Ravila, joka pohdiskeli useissa kirjoituksissaan niin suomalais-ugrilaisia numeruksia (1938) ja uralilaisen lauseen alkuperäistä rakennetta (1943) kuin taivutusopin (1945), sanaluokkien (1953), tempusten (1957) sekä nominaalilauseiden ja finiittimuotojen (1960) historiaa. Ravilan runsas tuotanto on huomionarvoinen monesta syystä. Hänen jälkeensä suomen kaukaisimpien kantakielten lauseoppia on pyritty rekonstruoimaan niin harvoin, että myös tulevien tutkijoiden kannattaa lukea Ravilansa tarkkaan ennen kuin keksivät pyöriä uudestaan. Nykylukijan silmiin Ravilan kirjoituksissa tosin pistävät lähinnä tuon ajan yleiset mutta metodologisesti perusteettomat oletukset rekonstruoitavissa olevien kantakielten rakenteellisesta primitiivisyydestä, mutta nämäkin tutkimukset ovat tarjonneet myöhemmille tutkijoille jättiläisen olkapäät, joilta uusia 
maisemia on ollut helppo katsella. Erityisen kaukonäköinen, mutta suuremmatta huomiotta jäänyt piirre itse lähinnä läntisimpiin uralilaiskieliin keskittyneen Ravilan kieliopillisissa pohdinnoissa on taaja viittailu samojedikieliin, joihin monet muut niin sanottujen suomalaisugrilaisten kielten tutkijat tuohon aikaan suhtautuivat varsin etäisesti; myöhempi tutkimus onkin osoittanut, että samojedi avaa jatkuvasti uusia, aiemmin huomiotta jääneitä näköaloja myös suomen kielen historiaan kielen kaikilla tasoilla (esim. Salminen 2014).

Uudemmalta ajalta on muistettava ennen kaikkea Virittäjän pitkäaikainen päätoimittaja, fennistiikan ja fennougristiikan monitoimimies Terho Itkonen. Valtaosa hänen jopa 187 Virittäjän-kirjoituksestaan käsitteli suomen kieltä ja sen huoltoa, mutta uransa hän aloitti itämerensuomalais-saamelaisilla etymologioilla jo parikymppisenä (Itkonen 1953). Myöhemmin Itkonen päätyi muun muassa laajoihin itämerensuomalaisten kielten syntyä käsitteleviin synteeseihin (esim. Itkonen 1983), joskin enimmät etäsukukieliin keskittyvät tutkimuksensa hän julkaisi Virittäjää fennougristisemmilla foorumeilla (esim. Itkonen 1992, 1997). Yhtä kaikki, Itkonen ja muut edellä mainitut sekä kymmenet tässä mainitsematta jäävät fennougristit ovat 125 vuoden aikana julkaisseet Virittäjän sivuilla runsaita ja monipuolisia tutkimuksia, joiden ansiosta uralilainen kielikunta on kiistatta yksi parhaiten tunnetuista kielikunnista ja uralilainen kantakieli yksi luotettavimmin rekonstruoiduista muinaisista kantakielistä (esim. Campbell 1998: 164-165). Hovdhaugen ym. (2000: 550) arvelevatkin, että klassinen historiallis-vertaileva uralistiikka on Suomen merkittävin anti 1900-luvun kansainväliselle kielitieteelle eikä ikääntymisen merkkejä ole juurikaan nähtävissä.

\title{
4 Linjapuheita, kansanvalistusta ja lävistyssuunnitelmia
}

\author{
Virittäjä ei esiinny korkeatieteellisen aikakauskirjan \\ vaatimuksilla eikä ole siksi aiottu, vaan sen tarkoituksena \\ on olla yhdyssiteenä Suomen kansan henkisen elämän \\ tutkijain ja kaikkien tätä tiedonalaa harrastavien välillä. \\ (Virittäjä 1897: 1)
}

Kun Virittäjää tarkastelee fennougristisena julkaisuna, huomio kiinnittyy nopeasti muuhunkin kuin siihen, että kyseessä on ennen kaikkea suomeen ja Suomeen keskittyvä aikakauslehti. Suorastaan poikkeuksellista on nimittäin se, että juuri Virittäjä on foorumi, jossa suomalaiset 
fennougristit ovat tavallisimmin julkisesti pohtineet fennougristiikan tehtäviä, tavoitteita ja tulevaisuutta. 1900-luvun alun kielitieteen pääideologi E. N. Setälä tosin esitti suurimmat visionsa muualla - fennougristiikan osalta usein Suomalais-Ugrilaisen Seuran Aikakauskirjassa ja itse perustamassaan Finnisch-Ugrische Forschungenissa. Virittäjän myöhempi historia sisältää kuitenkin monia kirjoituksia otsikoin kuten "Suomalaisugrilaisesta kielentutkimuksesta ja sen lähimmistä tehtävistä" (Toivonen 1934), "Suomalaisugrilaiset kielet ja yleinen kielitiede" (Ravila 1949), "Suomalaisen fennougristiikan tulevaisuudesta" (Alhoniemi 1977), "Suomen fennougristiikan tulevaisuudennäkymiä" (Alhoniemi 1996) ja "Suomen fennougristiikan tilasta ja tulevaisuudesta" (Grünthal \& Laakso 2001). Paljon huomiota ovat saaneet monet Paavo Ravilan kielitieteen tehtäviä pohtineet kirjoitukset, mutta yleensä fennougristiikkaa laajemmissa yleislingvistisissä tai suppeammin fennistiikkaan rajoittuneissa konteksteissa (esim. Hakulinen 1993; Karlsson 1997; Itkonen 1999: 47-61).

Monet, jopa kymmenet fennougristien ohjelmalliset puheenvuorot Virittäjässä perustuvat erilaisiin julkisiin esitelmiin, joissa puhutellaan yhtaikaa laaja-alaisesti oppinutta suppeaa lähipiiriä ja pienemmin tiedoin varustettua laajaa yleisöä. Tällaiset tekstit tarjoavat nykylukijallekin monien yksittäisten tiedonjyvien lisäksi kiintoisan näköalan fennougristiikan yleiseen kehitykseen - ja myös yleiseen muuttumattomuuteen. Pysyvyyttä edustaa muun muassa se, että meidänkin aikanamme todetaan usein, että suomalais-ugrilaisilla kielillä olisi paljon annettavaa myös synkroniselle kielentutkimukselle, ikään kuin fennougristit olisivat vasta hiljakkoin havahtuneet arvostamaan äännehistorian ja etymologian lisäksi myös yleistä kielitiedettä ja sen tarjoamia kansainvälisiä näköaloja ja mahdollisuuksia. Kuitenkin esimerkiksi jo Toivonen (1934: 387) virkaanastujaisesitelmässään totesi, että olisi ”esim. saatava muistakin kielistä sellaiset perinpohjaiset deskriptiiviset kieliopilliset esitykset, jollainen on esim. KONRAD NIELSENin mainio Norjan lapin kielioppi, jotta muoto-, johto- ja merkitysopin tutkimus kävisi vähänkin helpommaksi”. Hieman myöhemmin - yli 70 vuotta sitten - myös Ravila harmitteli alan yksipuolisuutta varsin nykyaikaisilta kuulostavin äänenpainoin: 
- - morfologia ja varsinkin syntaksi ovat jääneet pahasti syrjään, ja kuitenkin juuri nämä tieteenhaarat voisivat tarjota arvokasta ainesta yleiselle kielitieteelle. Kun viime vuosikymmeninä kaikkialla on harrastus suuresti kasvanut yleisluonteisia kysymyksiä kohtaan, on samalla voinut panna merkille, että myös mielenkiinto suomalais-ugrilaisia kieliä kohtaan on kasvanut. Nyt eivät enää kiinnosta yksityiset lainasanat, vaan suomalais-ugrilaisten kielten rakenne, äännesysteemi, muoto- ja lauseoppi. Tätä heräävää ja kasvavaa mielenkiintoa ei saa päästää mielestä. Se velvoittaa fennougristeja tulemaan avuksi ja suuntaamaan tutkimuksensa sellaisten kysymysten selvittelyyn, jotka ovat omansa tuomaan lisävalaisua kansainväliseen keskusteluun. (Ravila 1949: 4)

Peräänkuulutettuihin uusiin tutkimusaloihin palaan seuraavassa luvussa, mutta Turussa tätä suuntausta alkoivat kehittää aktiivisesti jo 1950-luvulla mariin erikoistunut Eeva KangasmaaMinn sekä maria ja mordvaa tutkinut Alho Alhoniemi, jotka ovat julkaisseet suuren osan suomenkielisistä tutkimuksistaan Sananjalassa. Virittäjän lukijoille uusia maisemia Alhoniemi (1977) on esitellyt esimerkiksi kuvaillessaan Turun yliopistossa suomen kielen lauseopin arkiston rinnalle kehitetystä "ATK-menetelmiä hyväksi käyttävästä" mordvalaiskielten korpushankkeesta:

Eikä hankkeessa ole kyse mistään iäisyysprojektista. Laskelmieni mukaan 2000 -2 500 sivun taivutusopillinen koodaus vaatisi kieltä kohti — jos työtä ohjaamaan saadaan kielen hyvin tunteva asiantuntija $-4-5$ työvuotta; lisäksi tarvittaisiin jonkin verran varoja lävistykseen ja tietokoneen käytöstä aiheutuviin kustannuksiin. (Alhoniemi 1977: 191)

Alhoniemi (mas.) korostaa, että hän ei tarkoita tietotekniikan ihannointia, mutta humanistisessakin tutkimuksessa "tietokoneen apu on kuitenkin syytä ottaa vastaan kaikissa niissä tapauksissa, joissa se ratkaisevasti helpottaa esim. materiaalin käsittelyä’. Tähän olemme jo tottuneet. Myös mainitun korpushankkeen perilliset ovat edelleen tutkijoiden käytössä.

Fennougristiikan olemusta pohtivissa kirjoituksissa toistuvat yhä uudestaan käsitykset tieteenalan pysyvyydestä sekä suomen ja sen sukukielten tutkimuksesta kansallisena tieteenä, 
johon juuri Suomessa on parhaat edellytykset ja suurimmat kansalliset tarpeet, ja joka on myös merkittävä tieteemme myyntivaltti:

Suomen fennougristisen tutkimuksen vientimarkkinat ovat olleet maailman arvostetuimmat - yksikään huomattava fennougristiikan tutkija, olipa hän neuvostoliittolainen, saksalainen, amerikkalainen tai japanilainen, ei voi kulkea suomalaisen fennougristiikan tähänastisten saavutusten ohi. (Alhoniemi 1977: 192)

Tällaiset fennougristiikan päätuloksia ja -tavoitteita koskevat kirjoitukset ovat tekstilaji, jolle ei löydy yhtä näkyviä vastineita edes Virossa tai Unkarissa julkaistavista fennougristisista tai kansallisemmista aikakauslehdistä (unkarilaisen fennougristiikan itsetutkistelusta ks. kuitenkin Domokos 2002: 341-345). Tämän luvun alun lainaus muistuttaa siitä, että Virittäjän (1897: 1) alkuperäiset tavoitteet olivat melko kansanläheiset. Samaan suuntaan viittaavat myös Erkki Itkosen sanat Paavo Ravilan täyttäessä 60 vuotta:

Virittäjällä on Paavo Ravilan merkkipäivänä erityinen syy lämpimiin onnentoivotuksiin ja kiitoksiin, sillä päivänsankarin bibliografian silmäily osoittaa hänenkin kuuluvan niihin tyypillisiin suomalaisiin kielimiehiin, joille tämä aikakauskirja on ollut kaikkein useimmin käytetty foorumi. Havainto voi tässä tapauksessa tuntua hiukan yllättävältä, mutta epäilemättä prof. Ravila on julkaistessaan laajakantoisten teoriainsa keskeiset ideat ainakin supistelmina suomeksi äidinkielemme tutkimuksen äänenkannattajassa tahtonut muistuttaa siitä, että vertaileva fennougristiikka ei ole eksklusiivinen, fennistiikasta erillinen tieteenhaara, vaan pohja, jolta viimeksimainittu elimellisesti kasvaa. (Itkonen 1962: 164)

Fennougristien norsunluutorneista katsottuna Virittäjä on todellakin ollut se foorumi, jossa suomalainen fennougristi on voinut luontevimmin toteuttaa Virittäjän alkuperäisintä ja yliopistojen kolmatta tehtävää jo yli sata vuotta ennen kuin sitä on statuutteihin ja yliopistolakeihin kirjattu - onhan Virittäjän lukijakunnasta suuri osa aina ollut suomen kielen opettajia kautta maan. Mielenkiintoiseksi tämän genren tekee sekin, että perinnettä ovat ylläpitäneet profiililtaan varsin monenlaiset fennougristit Toivosen ja Erkki Itkosen kaltaisista vähä-äänisemmistä tutkijoista Ravilan kaltaiseen ideologiin ja yhteiskunnalliseen vaikuttajaan. Samanhenkisiä näköaloja Suomen kielitieteilijöille ovat tarjonneet myös runsaat 
alan merkkipäivä- ja muistokirjoitukset sekä kirjaesittelyt, joita ovat laatineet myös ne fennougristit, jotka eivät muuten ole Virittäjän sivuilla vierailleet.

Fennougristeille suomi on kansainvälinen tieteen kieli ja Virittäjän välityksellä suomalaiset ovat saaneet myös ulkomaisia vaikutteita ensimmäisen käden lähteistä. Tietojaan ovat jakaneet muun muassa norjalainen Knut Bergsland saamesta, unkarilaiset László Keresztes mordvasta ja Magda Kövesi komista, myös komilaiset V. I. Lytkin ja Igon Mõsšeg komeista sekä neuvostoliittolainen Natalja Tereštšenko samojedikielistä. Virolaisen Julius Mägisten 34 kirjoitusta lukuisista kielistä ulottuivat kuudelle vuosikymmenelle (1924-1976). Uralilaisten kielten puhujien valtaosan puhuma unkari tosin on saanut Virittäjässä suhteellisen vähän itsenäistä huomiota. Äänne- ja sanahistoriallisissa tutkimuksissa sitä ei tietenkään ole voitu sivuuttaa, mutta muuten unkarilaisen kielitieteen merkitys Virittäjässä on paljolti rajoittunut satunnaisten kirjojen, merkkipäiviään viettäneiden tutkijoiden ja konferenssien esittelyyn. Toisaalta harvat fennistitkään ovat pyrkineet edistämään omaa alaansa esimerkiksi Magyar Nyelvőrissä, "Unkarin Virittäjässä".

Virittäjän lähihistoriaan katsottaessa huomio kiinnittyy siihen, että sitä mukaa kun kirjoittajakunnan painopiste on siirtynyt professoreista aiempaa runsaslukuisempiin väitöskirjatutkijoihin, yleissivistävien mutta samalla tieteenalan eksistentiaalisia kysymyksiä pohdiskelevien kirjoitusten funktiossa toimivat enenevässä määrin Virittäjän verkkoliitteessä ilmestyvät väitöksenalkajaisesitelmät. Fennougristien puheista käy tällöinkin toistuvasti ilmi vanha totuus, että tutkittavaa on paljon, kielten dokumentoimisella ja kuvaamisella kiire ja suomalais-ugrilaisten kielten tutkijoilla on poikkeuksellisen hyvät mahdollisuudet tehdä suomea ja sen sukukieliä tunnetuksi myös kansainvälisessä lingvistiikassa (esim. Idström 2010, Turunen 2010, Puura 2019).

Fennougristiikkaa nimenomaan Virittäjän valossa peilatessa merkillepantavaa on myös se, että fennistiikasta poiketen fennougristiikan kehitystä eivät juurikaan ole leimanneet merkittävät uudet avaukset saati näkyvät paradigmanvaihdokset ja niihin liittyvä vanhan hylkääminen. Pikemminkin fennougristeilla on jo yli sadan vuoden ajan ollut tapana todeta, että töitä on vielä paljon ja monet tärkeät hankkeet yhä tavalla tai toisella kesken. Setälän kuuluisasta astevaihteluteoriastakin luovuttiin verrattain hitain liikkein (ks. Juusela 2006: 150-156). Ehkä koko Virittäjän historian näkyvin poikkeama fennougristien hiljaisesta arjesta oli Kalevi Wiikiin henkilöitynyt vilkas keskustelu suomalaisten juurista vuosina 
1996-1998. Keskustelu sai alkunsa Eve Mikosen (1996) puheenvuorosta Virittäjässä, josta se levisi pian myös muille tieteellisille areenoille ja yleistajuiseen mediaan. Fennougristit torjuivat Wiikin uhkarohkeat teoriat yksimielisesti, ja nyt tuo välikohtaus on käytännössä enää muisto tutkimushistorian lehdillä (Juusela mts. 211; Salminen 2008: 204; Tirkkonen 2012).

Virittäjän virittämä alkuperäkeskustelu jää joka tapauksessa vaikuttavaksi esimerkiksi siitä, kuinka vankka yksimielisyys fennougristien keskuudessa vallitsee niistä yleisistä periaatteista, joilla muinaisia kielikontakteja ja muuta kielihistoriaa sekä kansojen ja kulttuurien esihistoriaa on tutkittava, sekä siitä, kuinka pyhinä kielikunnan syvimpiä syntykysymyksiä pitivät myös ne kielikunnan nykyisyyteen omissa tutkimuksissaan keskittyneet fennougristit, jotka keskusteluun osallistuivat (Tirkkonen 2012). Yksimielisiä oltiin ennen kaikkea siitä, millä tavalla historiallista kielitiedettä tulee harjoittaa, vaikka yleistä konsensusta pohjoisen Euraasian kielellisestä menneisyydestä ei toki sinänsä ole saavutettu.

\title{
5 Synkronista ja soveltavaa kielitiedettä
}

\author{
Jo satakunta vuotta on joko tahallaan tai, kuten toivoisi, \\ kaikessa viattomuudessa ja tietämättömyydessä \\ työskennelty Suomeen kuuluvien lappalaisten \\ suomalaistuttamiseksi, eikä vieläkään ole päästy etemmä \\ kuin että Inarin lappalaiset murtaen puhuvat suomea, paitsi \\ lapset ja Paatsjoen-niskan kylye, jotka eivät vielä ole \\ sitäkään taitoa saavuttaneet. (Elias Lönnrot v. 1842 \\ Tunkelon 1902: 58 mukaan)
}

Vaikka suomalais-ugrilainen kielentutkimus on ollut perimmäisiltä tavoitteiltaan historiallista, kaikki suomalais-ugrilaisten kielten tutkimus ei suinkaan ole diakronista. Turun yliopistossa on keskitytty synkroniseen kielentutkimukseen Helsingin yliopistoa aiemmin, mutta turkulaiset fennougristit ovat usein julkaisseet suomenkieliset tutkimuksensa Virittäjän sijaan sikäläisen Suomen Kielen Seuran kustantamassa Sananjalassa. Helsingissä synkronisen fennougristiikan pioneeri on ollut Raija Bartens, joka niin ikään on julkaissut vain pienen osan merkittävästä tuotannostaan Virittäjässä. Bartensin, Alho Alhoniemen ja 
Eeva Kangasmaa-Minnin kaltaisilla tutkijoilla on toki ollut seuralaisia ja seuraajia. Juusela (2006: 208-212) vilkuilee suomen sukukielten tutkimusta lähihistoriassa, mutta tässä yhteydessä on kiintoisampaa katsoa kauemmas historiaan.

Edellä nähtiin jo Toivosen (1934: 387) ja Ravilan (1949: 4) kaivanneen fennougristeilta enemmän kieliopin kuvauksia ja synkronista tutkimusta, mutta nämä toiveet eivät ole tarkoittaneet, etteivätkö he olisi nähneet tällaista fennougristiikkaa harjoitetun jo omana aikanaan ja aiemminkin. Toivosen mainitsema Konrad Nielsen sai 60 vuotta täyttäessään ylistystä myös nuorelta Ravilalta:

Vaikka suuri oppineisuus ja suorastaan ilmiömäinen kielitaito ovat tehneetkin Nielsenille mahdolliseksi julkaista tutkimuksen jopa turkin kielen painosuhteista, niin on hänen tieteellisen toimintansa keskuksena kuitenkin ollut lapin kielen valtamurteen, ruijanlapin, tarkka ja perinpohjainen selvittäminen. Tänä päivänäkin me näemme hänet väsymättömästi uurastamassa saman päämäärän hyväksi, päämäärän, jota kunniakkaampaa norjalainen fenno-ugristi ei voisi itselleen asettaa. (Ravila 1935: 392)

Nielsenin työ ruijanlapin eli pohjoissaamen grammaatikkona ja leksikografina on todellakin mittavimpia yhden suomalais-ugrilaisen kielen kuvaamiseen keskittyneitä henkilösuorituksia. Myös pienistä puroista on syntynyt suuri virta: Jo Ravilan omat lauseopilliset tutkimukset sisältävät suuret määrät "runsasta, luotettavaa ja hyvin järjestettyä ainesta" (Ravila 1951: 120), joiden usein perimmäisiltä motiiveiltaan diakroninen tarkastelu on seurausta synkronisesta deskriptiosta. Ravila itse aloitti mordvan tutkijana ja julkaisi Virittäjässäkin pienen tutkimuksen mordvan johto-opin alalta (Ravila 1933a). Marin sananmuodostusta on lehdessä kuvannut Erkki Itkonen (1960, 1966) ja sijojen semantiikkaa Alhoniemi (1969). Itkosen (1960: 316-319) esitys marin elatiivisen gâč́-aineksen universaaleja uhmaavasta degrammatikalisaatiosta eli sijasuffiksin lohkeamisesta postpositioksi olisi jo kauan sitten ansainnut myös yleislingvistien huomion (vrt. Norde 2009) - uralilaisten kielten synkroniseksikin aiottu tarkastelu tarjoaa usein väistämättä myös kiinnostavia diakronisia näköaloja.

Suomen sukukielten tutkimus oli pitkään historioivaa senkin takia, että Venäjän vallankumouksen jälkeen fennougristit joutuivat keskittymään tsaarinaikaisten kokoelmien tutkimiseen ja puhtaaksikirjoittamiseen. Poikkeuksellinen välivaihe oli jatkosota, jonka 
aikaiset vankileirit tarjosivat kauan odotetun mahdollisuuden saamea kaukaisempien etäsukukielten tutkimiseen. Aarni Penttilä (1942: 149) kuvaa kirjoituksessaan "Suomenheimoiset sotavangit kielenoppaina" haltioituneena, kuinka pitkän odotuksen jälkeen oli "täällä ikäänkuin patoutuneena sitä tieteellistä mielenkiintoa, jota meillä hyvin ymmärrettävistä syistä tunnetaan ja on tunnettava entisen itärajamme takaista materiaalia kohtaan”. Sotavankeja hyödynsi aktiivisesti suuri joukko suomalaisia ja ulkomaisiakin kielentutkijoita (Salminen 2008: 151-155; Kokkonen 2010).

Virittäjän sivuilla eniten huomiota saaneita etäsukukieliä ovat joka tapauksessa saamelaiskielet. Vaikka huomattava osa saamen synkronisesta tutkimuksesta onkin ollut kytköksissä historialliseen kielentutkimukseen ja sen myötä suomenkin kielen menneisyyden valaisemiseen, osa saamea ja saamelaisia käsittelevästä tutkimuksesta on luonteeltaan niin käytännöllistä, että sitä voi luonnehtia soveltavaksi kielitieteeksi.

2020-luvun Suomessa kielten uhanalaisuudesta ja kielivähemmistöjen oikeuksista puhutaan niin paljon, että historiaa tuntematon voi luulla ilmiötä jokseenkin uudeksi. Tätä taustaa vasten on kiinnostavaa palata vuoden 1902 Virittäjään ja sen kautta aina 1840-luvulle asti. Virittäjän merkittävimpiin perustajiin, toimittajiin ja kirjoittajiin kuuluva E. A. Tunkelo (1902) esittää kirjoituksessaan "Elias Lönnrot Suomen lappalaisten äidinkielen puolesta" seikkaperäisen ja myötäelävän kuvauksen siitä, kuinka antaumuksellisesti Lönnrot kirjoitti ja työskenteli myös saamelaisten oikeuksien puolesta. Vuonna 1842 Lönnrot kirjoitti epäsuorasti myös ruijansuomalaisten eli sittemmin kveeneinä tunnetun kielivähemmistön asemasta, johon hän oletti suomalaisten lukijoidensa helpommin samaistuvan. Lönnrot paheksui niin saamelaisten kirkkoelämän ja koulunkäynnin edellyttämää pakkosuomea kuin sitä, että "suomalaiset ovat laiminlyöneet Suomen lapin murteiden tutkimisen", vaikka maailma on "täpösen täynnä kielentutkijoita — — ja nämä ovat milloin tahansa valmiit kirjottamaan pitkiä tutkimuksia kaikennäköisistä seikoista, kuten esim. siitä, onko Tacitus tai Sallustius kirjottanut ac tai atque, cum vai quum j. n. e. jossakin lauseessaan" (Tunkelo 1902: $55)$.

Itse historian ensimmäisen inarinsaamen kieliopin laatineen Lönnrotin (1854) jälkeen saamen tutkimus voimistui suuresti ja saamelaiskieliin viitataankin Virittäjän 125-vuotisen historian alkupuolella joka vuosi ellei jopa joka niteessä. Selvästi synkronista ja soveltavaa kielentutkimusta edustaa esimerkiksi Erkki Itkosen (1951) kuvaus pohjoisaamen ortografian 
kehittämisestä 1900-luvun alkupuoliskolla. Yhteispohjoismainen pohjoissaamen ortografia saatiin luotua vasta 1970-luvulla; tätä prosessia kuvaa seikkaperäisesti Samuli Aikio (1987). Itkosen ja Aikion omakohtaiset kuvaukset työn ajoittaisesta tuskastuttavuudesta esittävät fennougristien ja tavallisen kansan vuorovaikutuksen eräänlaisena kehitysyhteistyönä:

- - Saatetaan myös kysyä, onko oikein, että kielimies käy tällaisista seikoista neuvottelemaan henkilöiden kanssa, jotka teoreettisen tiedon puuttuessa ottavat melkein kaiken tunneasian kannalta. Tähän voinee vastata, että on suorastaan pakko menetellä niin, jos nuo neuvottelukumppanit samalla muodostavat sen piirin, jonka varassa asianomaisen kielen kehittely ja kirjallinen viljely käytännöllisesti katsoen kokonaan on. Tärkeämpää kuin mi t e n meillä tunturilappia kirjoitetaan, onkin se, että lappia vakavasti pyrittäisiin käyttämään niin suullisesti kuin kirjallisestikin. (Itkonen 1951: 182)

- - Mutta tällaiset demokratian sivuvaikutukset täytyy kestää. Erkki Itkosen virittämää retorista kysymystä ja hänen siihen antamaansa vastausta mukaillakseni: on pakko keskustella kielen käytöstä ja huollosta niiden kanssa, joiden varassa kielenkäyttö on, olivatpa he asiantuntevia tai eivät. (Aikio 1987: 478)

Kielellisiin oikeuksiin ja kielten elvyttämisen mahdollisuuksiin viitataan varhain myös muiden, erityisesti itämerensuomalaisten heimokieltemme suhteen. Karjalan kielen asiaa ajanut E. V. Ahtia pyrki kääntämään pessimismin optimismiksi:

On kuitenkin nykyaikana nähtävänä merkillisiä ilmiöitä päinvastaiseen suuntaan. Ikivanhat kielet herätetään henkiin: hebreankieli on jälleen tulemaisillaan eläväksi kieleksi, irlanninkieli leviää uudestaan ammoin menettämilleen alueille, on syntynyt ukrainan, valkovenäjän, tataarin, tšuvaššin kirjakielet, Norjan „maakieli“, Ranskan provencelainen kieli y. m. (Ahtia 1920: 67)

Tällä vuosisadalla kielen ja kansallisuuden suhdetta sekä revitalisaatiota on käsitelty samaan tapaan etenkin itämerensuomalaisia ja saamelaisia vähemmistökieliä silmällä pitäen (esim. Lindgren 2001; Olthuis 2003; Sarivaara 2012; Puura 2018), mutta vielä 1800- ja 1900-luvun taitteen Virittäjässä vakavimpana ja aivan aiheellisena huolena oli suomen ja viron kielen tulevaisuus. 


\section{Fennougristiikka ja Virittäjä 2000-luvulla}

Jos fennougristiikka onkin nykysuomalaisen yhteiskunnan ja koulutuspolitiikan kannalta fennistiikan pieni, marginaalinen taustaosanen, kansainväliseltä tai tieteenteoreettiselta kannalta katsellessa tämä suhde kääntyy päälaelleen. Kärjistäen voisi väittää, että fennistiikan irrottautumiselle fennougristiikasta on yhteiskunnalliset ja tiedepoliittiset syynsä mutta ei tieteellisiä perusteita... (Grünthal \& Laakso 2001: 262)

Edellä on tarkasteltu fennougristiikan ja Virittäjän yhteistä taivalta ennen kaikkea 1900luvulla. Vaikka Suomalais-Ugrilaisen Seuran ja koko suomalaisen fennougristiikan suurimmat yhteisponnistukset, usein kymmeniä työvuosia vieneet sukukielten sanakirjahankkeet, ovat toteutuneet muualla kuin tämän lehden sivuilla, muuten alan kehityksestä voi saada varsin kattavan kuvan jo pelkkää Virittäjää lukemalla. Aivan viime vuosikymmenten kehitystä on vaikeampi hahmottaa pelkästään yhden lehden valossa, sillä tieteellisen julkaisemisen kansainvälistyessä ja muutenkin laajentuessa Virittäjäkin uhkaa jäädä vain yhdeksi julkaisukanavaksi muiden joukossa. Suomen sukukielten ja etenkään etäsukukielten näkyvyys Virittäjässä ei niinkään ole vahvistunut (Juusela 2006: 208-209; Korppi-Tommola 2011: 119) vaan pikemminkin heikentynyt, kuten jo Kangasniemi (1988) on 1900-luvun loppupuolen osalta osoittanut. Vallan dramaattisia muutoksia ei kuitenkaan ole nähtävissä, vaan pitkässä perspektiivissä fennougristiikan ja Virittäjän suhde näyttää jatkuvan periaatteessa entisellään (esim. Spets 2021).

Fennougristiikan identiteetin ja tulevaisuuden pohdinta Virittäjän sivuilla on jatkunut myös 2000-luvulla. Grünthal ja Laakso (2001) maalaavat fennougristiikasta värikkään kuvan esittäessään kokonaiset viisi erilaista fennougristiikan lajia: kansallisromanttisen, puristisen, sosioekologisen, politisoidun ja postmodernin. Virittäjässä on pysyttäydytty lähinnä puristisessa fennougristiikassa eli vertailevassa tai deskriptiivisessä kielentutkimuksessa, jonka kohteena ovat suomalais-ugrilaiset kielet itsessään, eivät niinkään niiden puhujien entiset, nykyiset tai tulevaisuuteen kuvitellut tarpeet. Uusimpana aluevaltauksena voisi pitää Alhoniemenkin (1996) kaipaamaa sosioekologista fennougristiikkaa, mutta kuten edellisessä luvussa nähtiin, sitäkin on harrastettu jo Lönnrotin aikoina. 
Fennougristiikan ja fennistiikan suhdetta Grünthal ja Laakso (2001) pitävät hieman ristiriitaisena. Numeerisesti mitattuna edellinen näyttäisi pitkään olleen jälkimmäisen marginaalinen taustaosanen, ja tämän fennougristit ovat itsekin jo pitkään myöntäneet (esim. Alhoniemi 1977), mutta sisällöllisesti he haluavat yhä nähdä pikemminkin fennistiikan oman tieteenalansa versona:

Mutta onko fennougristiikka tosiaankin vain fennistiikan taustoittaja ja lisävalaisija? Eikö paremminkin ole niin, että fennougristiikka on fennistiikan ympärillä kuin valkuainen keltuaisen: suomen kielen erikoiskysymyksistä on vaikea päästä laajempiin ympyröihin muuten kuin koskettamatta suomalaisittainkin fennougristiseksi määriteltävää aluetta? Tämän huomaa tiukoinkin perusfennisti ulkomaisiin tutkijaympyröihin tai maallikoidenkin pariin mennessään. (Grünthal \& Laakso 2001: 262)

20 vuotta edellä lausutun jälkeen en ole yhtä vakuuttunut siitä, että perusfennisti - kuka ja millainen hän onkaan - kokee joutuvansa maailmalla suuriin vaikeuksiin ilman fennougristista taustaa. Hyötyä sellaisesta kuitenkin aina on, sillä germaanisten ja romaanisten kielten dominoimassa yleisessä kielitieteessä suomi on ja pysyy viehättävän erilaisena eurooppalaisena kielenä juuri syntyperänsä ansiosta. Myös fennougristit ovat oppineet käsittelemään ja esittelemään omia kieliään aiempaa laajemmassa typologisessa perspektiivissä. Hyviä näytteitä perinteisen fennougristisen ja uudemman typologisen tiedon yhdistämisestä ovat Grünthalin (2005) artikkeli itämerensuomen adpositioiden sanajärjestyksestä ja sen kehityksestä sekä Spetsin (2021) tuore katsaus evidentiaalisuuden ja modaalisuuden ilmaisukeinoihin marissa.

Toisaalta erityisesti synkronisen, deskriptiivisen fennougristiikan omaksumat typologiset lähestymistavat ovat johtaneet kansainvälisempien julkaisujen suosimiseen, jolloin suomenkieliseen Virittäjään yhä kanavoituvassa fennougristisessa tutkimuksessa painottuu ikään kuin vanhanaikaisempi, etenkin sanahistoriallinen tutkimusperinne - kiinnostaahan vaikkapa Tampereen ja Tammerkosken saamelainen etymologia *Tẹpęl|kōške 'suvantokoski' (Rahkonen 2011) keskimääräistä Virittäjän lukijaa paljon enemmän kuin pohjoissaamen lauseopilliset finessit, joista on yleensä tarkoituksenmukaisempaa kirjoittaa saameksi tai englanniksi. Voisikin ehkä sanoa, että suomalais-ugrilaisten kielten etymologian 
ja äännehistorian tutkijoiden absoluuttinen määrä on kautta Virittäjän historian pysynyt suunnilleen entisellään, mutta esimerkiksi synkronisen lauseopin tutkijoiden lisääntyminen sitten 1800-luvun on havaittavissa muualla selvästi paremmin kuin Virittäjässä - ikään kuin vastauksena Kotikielen Seuran perustajan August Ahlqvistin (1872: 51) toteamukseen, että "lauserakennus" eli syntaksin tutkimus on "oikeaan kielitieteesen kuulumaton tutkinnonala".

Fennougristiikan kova ydin on joka tapauksessa kestänyt aikaa paremmin kuin fennistiikka (ks. esim. Itkonen 1999: 47-61; Juusela 2006: 166-174; Kurki \& Mustanoja 2019). Setäläläis-nuorgrammaattiseksi paradigmaksi kutsuttu äännehistoriallinen tutkimusperinne on kehittynyt äännehistoriallisen tutkimuksen nykymuotoon verraten maltillisesti (Grünthal \& Laakso 2001: 257; Holopainen ym. 2021), eikä missään nimessä ole koskaan varsinaisesti katkennut. Kuten Janhunen (2007: 56) asian ilmaisee, "fennougristiikka vältti sen rajun paradigmanmuutoksen, joka kohtasi Suomen fennistiikkaa 1970-luvulla, jolloin koko aikaisempi, diakroniaan ja dialektologiaan suuntautunut korkeatasoinen tutkimusperinne vaihtui väkivalloin 'modernin' kieliteorian malleihin” (ks. myös Laakso 2009: 84).

Aivan toisen tason paradigmoista on sitä vastoin kyse siinä, että kielikunnan muinaisuutta tutkivassa diakronisessa fennougristiikassa ja sen liepeillä on esiintynyt maltillisempia ja radikaalimpia tutkimusparadigmoja, joita on erottanut ennen muuta se, kuinka rohkeasti kielentutkimuksen tulokset on haluttu yhdistää arkeologian ja genetiikan tutkimustuloksiin (ks. esim. Mikone 1996; Janhunen 2001; 2007; Tirkkonen 2012). Niin keskeisiä kuin nämä kysymykset fennougristeille ovatkin, Virittäjä ei - edellä mainittua 1990-luvun lopussa käytyä Wiikin näkemysten herättämää keskustelua lukuun ottamatta - ole toiminut tämän keskustelun erityisnäyttämönä. Fennougristiikkaa kaiken suomalais-ugrilaisia kieliä koskevan tutkimuksen kattavana tieteenä eivät muuten niinkään kuvaa toisiaan seuraavat tai haastavat paradigmat, vaan kyse on pikemminkin laajasta ja monitahoisesta verkostosta (Laakso 2009).

Vaikka myös suomen sukukielten tutkijoiden työkenttä on jatkuvasti monipuolistunut, prototyyppisten fennistien ja fennougristien yhteinen pohja on kaventunut. Alkuperäinen yhteinen pohjahan on ollut puhuttujen kielten lähinnä maantieteellisesti tarkastelluissa murteissa, joita pitkin kielten puhuma-alueet ovat liittyneet toisiinsa ja herättäneet lukemattomia kielihistoriallisia kysymyksiä, joita fennougristit yhä ratkovat. Esimerkiksi Tampereen etymologisoiminen saamelaisten suvantokoskeksi (Rahkonen 2011) ei edellytä menetelmiä, näkökulmia tai tutkimusparadigmoja, jotka eivät olisi olleet vallassa jo 1800- 
luvulla. Fennistit sen sijaan ovat enimmäkseen löytäneet uusia tutkimuskysymyksiä muun muassa generatiivisen ja interaktionaalisen kielitieteen parissa ja jättäneet historiallisen dialektologian suureksi osaksi taakseen. Virittäjän ensimmäinen toimituskunta voisikin kokea meidän aikamme Virittäjän vieraammaksi kuin Suomalais-Ugrilaisen Seuran Aikakauskirjan, joskin jälkimmäisen kokema englanninkielistyminen voisi olla odottamaton yllätys.

Ehkä lähin uusi suomesta ja sen sukukielistä kiinnostuneita tutkijoita yhdistävä pohja on kielen ja identiteetin suhteita pohtiva sosiolingvistiikka tai kielisosiologia. Tällaista sosioekologista fennougristiikkaa edustaa muun muassa Puuran (2018) tutkimus vepsän puhujien kielellisistä identiteeteistä ja ideologioista. Toisaalta on muistettava, että fennougristisen tutkimuksen perimmäisenä syynä on alusta alkaen ollut koko pohjoisen Euraasian kielellinen ja etninen diversiteetti, ja nykyään tällaisen diversiteetin tutkimus tekee paluuta myös Suomen kielimaisemien tutkimukseen (ks. esim. Mantila 2007).

Fennistiikan ja fennougristiikan kaventunutta yhteistä pohjaa kuvaa myös se, että 2000-luvun Virittäjästä on helpompi poimia erilleen sen fennougristinen sisältö, kun taas sadan tai vain muutaman kymmenen vuoden takaisissa vuosikerroissa perkaustyö olisi paljon vaikeampaa, monin paikoin aivan mahdotonta. Samalla esimerkiksi itäisen ja etäisen lähisukukielemme vepsän tutkimus vaikuttaa irtautuneen Lauri Kettusen ajan fennistiikasta siinä määrin, että sen harjoittajat on entistä luontevampaa asemoida vepsää laajasti tutkineen Kettusen vierastamien "ugristien" puolelle. Voisikin arvella, että fennistiikka ja fennougristiikka ovat pian loitonneet toisistaan niin kauas, että luonnollisin uusi suunta on läheneminen.

Palautan vielä mieleen edellä luvussa 4 mainitun Erkki Itkosen (1962: 164) huomautuksen, että Paavo Ravila halusi julkaista "laajakantoisten teoriainsa keskeiset ideat ainakin supistelmina suomeksi äidinkielemme tutkimuksen äänenkannattajassa”. Ravila ei ollut ainoa fennougristi, joka on toisinaan julkaissut hyvinkin samansisältöisiä kirjoituksia niin suomalaiselle kuin kansainväliselle yleisölle. Tällaiselle ei ole enää yhtä suurta tarvetta, kun Virittäjän kielitaitoiset lukijat yliopistomaailman ulkopuolellakin saavat helposti eteensä myös kansainvälisillä foorumeilla julkaistua fennougristista tutkimusta. Toisaalta myös helposti lähestyttävällä, ehkä hivenen yleistajuistetulla suomenkielisellä fennougristiikalla on yhä käyttöä. Tätä tehtävää suorittavat edelleen etenkin väitöksenalkajaisesitelmät, mutta esimerkillisen vanhanaikaisena fennougristina voi mainita Santeri Junttilan, joka on vuosina 2013-2021 luvulla esitellyt omaa alaansa eli itämerensuomalaisten kielten etymologiaa, 
lainasanatutkimusta ja niitä sivuavia aiheita Virittäjässä jopa yhdeksässä lyhyessä mutta tiiviissä kirjoituksessa - esitelmissä, keskustelupuheenvuoroissa ja kantaa ottavissa kirjaesittelyissä - huolimatta siitä, että suurimmat tutkimuksensa hän on julkaissut muilla foorumeilla. Tällainen yhteydenpito on omiaan lujittamaan fennougristien ja fennistien mehenkeä.

\section{Yhteenvetoa}

Yleiseltä kannalta katsoen ei tietenkään ole mahdollista asettaa eri tieteenhaaroja mihinkään arvojärjestykseen — mitä laajempi, monipuolisempi ja syvempi on tieteellisen tutkimuksen pohja kansakunnan keskuudessa, sitä suurempi kansakunnan merkitys ja arvo kulttuurikansana -, mutta erikoisesti kansalliselta kannalta on oman maan ja heimon, sen historian, kulttuurin ja kielen tutkiminen kunkin kansan tärkeimpiä tieteellisiä tehtäviä, jonka suorituksen laadusta sen arvo kulttuurikansana paljon riippuu. (Toivonen 1934: 391)

Edellä olen tarkastellut suomalais-ugrilaisen kielentutkimuksen suhdetta 125-vuotiaaseen Virittäjään. Missään muualla ei ole koskaan julkaistu yhtä säännöllisesti ja yhtä paljon fennougristisesti relevanttia tutkimusta suomesta ja sen sukukielistä. Etenkin suomalaiset fennougristit ovatkin pitäneet Virittäjää oman alansa julkaisuna. Useimmat edeltävissä luvuissa mainitut fennougristit ovat luonnollisesti julkaisseet Virittäjässä myös lukuisia puhtaasti fennistisiä tutkimuksia, vaikka niiden merkitykselle ei tässä artikkelissa tilaa ole riittänytkään. Toisaalta tarkastelematta on täytynyt jättää myös monien Lauri Hakulisen ja Aarni Penttilän kaltaisten fennisteinä profiloituneiden tutkijoiden laaja fennougristinen lukeneisuus, jota ilman heidän näkemyksensä suomen kielestä ja sen kehityksestä olisivat olleet paljon suppeammat. Kaiken kaikkiaan Virittäjän historia osoittaa, että lehti on aina pitänyt myös suomen sukukieliä omana asianaan, vaikka esimerkiksi kansatieteelliset aihepiirit ja etenkin uralilaisten kansojen ulkopuolelle ulottuva tutkimus ovat jo aikaa sitten väistyneet sen sivuilta (ks. myös Erkkilä \& Palkki 2021). Näin Virittäjä ainakin osittain ylläpitää alkuperäistä tarkoitustaan "olla yhdyssiteenä Suomen kansan henkisen elämän tutkijain ja kaikkien tätä tiedonalaa harrastavien välillä” (Virittäjä 1897: 1). 
Edellä esitetyt lukuisat suorat lainaukset entisaikojen Virittäjistä näyttävät syystäkin vanhoilta, mutta niitä yhdistää omaan aikaamme se, että fennougristiikan kiinnostuksen kohteet ja niitä ohjaavat arvot eivät loppujen lopuksi ole missään vaiheessa radikaalisti muuttuneet. Vaikka kielitieteemme tutkimushistorian kuvauksissa erityistä huomiota on kiinnitetty Setälän ja Ravilan kaltaisiin provosoiviin ajattelijoihin, vähintään yhtä paljon suomen ja sen sukukielten tutkimusta ovat edistäneet Y. H. Toivosen tai hänen seuraajansa Erkki Itkosen kaltaiset omille tutkimusaloilleen omistautuneet ja ulkopuolisilta niukasti huomiota saaneet tutkijat.

Virittäjän ja suomalaisten fennougristien symbioosille erityisen leimallista on se, että hyvin monenlaiset fennougristit ovat pohtineet myös fennougristiikan suuria eksistentiaalisia kysymyksiä ääneen juuri Virittäjän sivuilla. Vastauksiakin on riittänyt. Myös suomen sukukieliä synkronisesti tarkasteleva tulee tavan takaa havainneeksi, että tämä tai tuo ilmiö onkin ensimmäisen kerran kuvattu Virittäjän sivuilla, esimerkiksi vain ohimennen jotain suomen kielen kehityksen erityiskysymystä pohdittaessa. Useimmat Virittäjän 125-vuotisen historian aikana esitetyt suomalais-ugrilaisen kielentutkimuksen tehtävät ja tulokset ovat vanhoja mutta eivät missään nimessä entisiä.

\section{Lähteet}

Aalto, PentTi 1958: Suomalais-ugrilainen Seura 1933-1958. - Suomalais-Ugrilaisen Seuran Aikakauskirja 60,1.

AHLQVIST, AUgUST 1872: Kieletär. Tutkimuksia, arvosteluja ja muistutuksia Suomen kirjallisuuden ja kielitieteen alalta. 2 Vihko. Helsinki: J. C. Frenckell.

AhtıA, E. V. 1920: Suuntaviivoja karjalan kirjakielen asiassa. - Virittäjä 24 s. 60-68.

AIKIO, SAMULi 1987: Yksi mieli, yksi kieli. Pohjoissaamen kirjakielen yhtenäistyminen.

- Virittäjä 91 s. 457-490.

AIRILA, MARTTI 1946: Maisteri Reino Peltolan Vepsän oppaan arvostelun johdosta. -

Virittäjä 50, s. 302-304.

ALHONIEMI, ALHO 1969: Välineen ilmaisemisesta tulosijan avulla tšeremissin kielessä.

- Virittäjä 73 s. 343-350.

1972: Synkronisen tutkimuksen merkityksestä fennougristiikalle. - Sananjalka 14 s. 5-

15. 
1977: Suomalaisen fennougristiikan tulevaisuudesta. - Virittäjä 81 s. 188-192.

1996: Suomen fennougristiikan tulevaisuudennäkymiä. - Virittäjä 100 s. 444-447.

BARTENS, RAIJA 1981: Suomalais-ugrilaisen kantakielen muoto- ja lauserakenteesta.

- Virittäjä 85 s. 101-108.

CAMPBell, Lyle 1998: Historical linguistics. An introduction. Edinburgh: Edinburgh University Press.

DOMOKOS, PÉTER 2002: Domokos Péter írásaiból. Budapest: ELTE.

ERKKILÄ, RIKU - PALKKI, TEEMU 2021: Hyvää tieteellistä proosaa: Virittäjän alat ja aiheet kautta aikojen. - Virittäjä $125 \mathrm{~s} . \mathrm{xxx}-\mathrm{xxx}$.

GRÜNTHAL, RıHO 2005: Miksi itämerensuomessa on prepositioita? - Virittäjä 109 s. 28-51.

GRÜNTHAL, RIHO - LAAKSO, JOHANNA 2001: Suomen fennougristiikan tilasta ja tulevaisuudesta. - Virittäjä 104 s. 256-267.

HAKulinen, Auli 1993: Kielitieteen suomalaisuus. - Pekka Laaksonen \& Sirkka-Liisa Mettomäki (toim.), Kauas on pitkä matka. Kirjoituksia kahdesta kotiseudusta s. 18-26.

Kalevalaseuran vuosikirja 72. Helsinki: Suomalaisen Kirjallisuuden Seura.

HolOPAINEN, SAMPSA - JUnTTILA, SANTERI - KALLIO, PETRI 2021: Lainasanatutkimus

Virittäjässä ja muualla. - Virittäjä 125 s. xxx-Xxx.

Hovdhaugen, Even - Karlsson, Fred - Henriksen, CArol - Sigurd, Bengt 2000: The history of linguistics in the Nordic countries. Helsinki: Societas Scietiarum Fennica.

HÄKKINEN, KAISA 2010: Nuorgrammatiikkaa vai ei? - Virittäjä 104 s. 577-588.

IDSTRÖM, ANNA 2010: Inarinsaamen käsitemetaforat. - Virittäjä 114 (4), verkkoliite. https://journal.fi/virittaja/article/view/4373.

ITKONEN, ERKKI 1951: Suomen tunturilapin kirjakielen kehitysvaiheet. - Virittäjä 55 s. 169183.

1957a: Suomalais-ugrilaisen kantakielen äänne- ja muotorakenteesta. - Virittäjä $61 \mathrm{~s}$.

1-23.

_ 1957b: Loppusanat prof. Kettuselle. - Virittäjä 61 s. 435-439.

1960: Tšeremissin kielen sanaliittojen suhteesta yhdyssanoihin ja taivutusmuotoihin.

- Virittäjä 64 s. 311-319.

— 1962: Paavo Ravilan täyttäessä 60 vuotta. - Virittäjä 66 s. 159-164.

1966: Eräästä tšeremissin adverbityypistä. - Virittäjä 70 s. 64-70.

ITKONEN, ESA 1999: Kielitieteen kääntöpuoli. Kirjoituksia vuosilta 1963-1999. Turku: Turun yliopisto.

ITKONEN, TERHO 1953: Punoa ja lapin bodnjât. - Virittäjä 57 s. 176-185. 
1983: Välikatsaus suomen kielen juuriin. - Virittäjä 87 s. 190-229.

1992: Ugrilaisten kielten karitiivista. - Pál Deréky, Timothy Riese, Marianne Sz.

Bakró-Nagy \& Péter Hajdú (toim.), Festschrift für Károly Rédei zum 60. Geburtstag s.

221-237. Wien \& Budapest: Institut für Finno-Ugristik der Universität Wien.

1997: Reflections on Pre-Uralic and the "Saami-Finnic protolanguage". - Finnisch-

Ugrische Forschungen 54 s. 229-266.

JANHUNEN, JUHA 1984: Altailaisen hypoteesin nykytila. - Virittäjä 88 s. 202-206.

1996: Fennougristiikan suhde naapuritieteisiin. - Tieteessä tapahtuu 7 s. 8-12.

2001: On the paradigms of Uralic comparative studies. - Finnisch-Ugrische

Forschungen 56 s. 29-41.

2007: Uudet tuulet uralistiikassa. - Tieteessä tapahtuu 2 s. 56-59.

JOKI, AULIS J. 1965: Kielisukulaisuuskysymyksiä. - Virittäjä 69 s. 352-358.

JUUSElA, KAISU 2006: Sata vuotta Virittäjää. Kotikielen Seuran aikakauslehden vaiheita vuosilta 1897-1996. Helsinki: Suomalaisen Kirjallisuuden Seura.

KALLIO, PETRI 2006: Suomen kantakielten absoluuttista kronologiaa. - Virittäjä 110 s. 2-25.

KANGASNIEMI, HEIKKI 1988: Mihin Virittäjä on virittänyt? - Virittäjä 92 s. 266-269.

KANNISTO, ARTTURI 1933: Das Publikationsprogramm der Finnisch-ugrischen Gesellschaft.

- Suomalais-Ugrilaisen Seuran Aikakauskirja XLVI,3.

KARLSSON, FRED 1997: Yleinen kielitiede Suomessa kautta aikojen. Helsinki: Helsingin yliopisto.

KETTUNEN, LAURI 1938: Onko vepsässä ollut astevaihtelua? - Virittäjä 42 s. 373-388.

— 1939: »Mielikuvituksellinen» kehitys kainala <*kä-en ala. - Virittäjä 43 s. 160-162.

— 1940: Karjalaisen heimon ja »karjalan kielen» iästä ja alkuperästä. Virittäjä 44, s. 129_ 144, 281-301.

1957: Problemaattista kantakielen genetiivissä ja paljossa muussa. - Virittäjä 61 s. 298 307.

KoKKONEN, PAUlA 2010: Jatkosodan komilaiset sotavangit kielenoppaina. - Paula Kokkonen \& Anna Kurvinen (toim.) s. 155-177.

KokKonen, PAUla - Kurvinen, AnNA (toim.) 2010: Kenttäretkistä tutkimustiedoksi. Uralica Helsingiensia 4. Helsinki: Helsingin yliopisto \& Suomalais-Ugrilainen Seura.

KORHONEN, MiKKO 1976: Suomen kantakielten kronologiaa. - Virittäjä 80 s. 3-18.

Korhonen, Mikko - Suhonen, SePPO - VirTARAntA, PertTi 1983: Sata vuotta Suomen sukua tutkimassa. 100-vuotias Suomalais-ugrilainen Seura. Espoo: Weilin + Göös.

KORPPI-TOMMOLA, AURA 2011: Kielivalistajien tarina. - Virittäjä 105 s. 118-121. 
KURKI, TOMMI - MUSTANOJA, LIISA 2019: Käänteitä, aaltoja ja risteymiä fennistisessä variaationtutkimuksessa. - Markus Hamunen, Tommi Nieminen, Tapani Kelomäki \& Hannele Dufva (toim.), Käänteitä ja käsitteitä. Näkökulmia kielitieteelliseen keskusteluun s. 87-120. Helsinki: Suomalaisen Kirjallisuuden Seura.

LAAKSO, JOHANNA 2009: Networks of Finno-Ugric studies. - Jussi Ylikoski (toim.), The quasquicentennial of the Finno-Ugrian Society s. 79-93. Suomalais-Ugrilaisen Seuran Toimituksia 258. Helsinki: Suomalais-Ugrilainen Seura.

LindGREN, ANNA-RIITTA 2001: Oikeus omaan kieleen. - Virittäjä 105 s. 239-255.

LÖNNROT, ELIAS 1854: Ueber den Enare-lappischen dialekt. Helsingfors: Societas scientiarum Fennicæ.

MANTILA, HARRI 2007: Hesan ja Stadin muuttuvat murteet ja kielet. - Virittäjä 111 s. 402408.

MiKONE, EvE 1996: Suomalais-ugrilaisia kieliä puhuvan väestön alkuperä. - Virittäjä $100 \mathrm{~s}$. $401-422$.

NIELSEN, KONRAD 1912: Lappisk som gjenstand for videnskabelig forskning.

Tiltrædelsesforelæsning holdt ved Kristiania universitet 25. mars 1912. Kristiania: Aschehoug.

NORDE, MurIEL 2009: Degrammaticalization. Oxford: Oxford University Press.

OLTHUIS, MARJA-LIISA 2003: Uhanalaisen kielen elvytys: esimerkkinä inarinsaame. Virittäjä 107 s. 568-579.

PAUNONEN, HeIKKI 1976: Kotikielen Seura 1876-1976. - Virittäjä 80 s. 310-432.

Peltola, Reino 1946: Vepsää suomalaisille. - Virittäjä 50 s. 179-185.

PENTTILÄ, AARNI 1942: Suomenheimoiset sotavangit kielenoppaina. - Virittäjä 46 s. 148 160.

PUURA, ULRIIKKA 2018: Vähemmistökielen osaaminen, äidinkieli, juuret vai passi?

Vepsäläiseksi identifioituminen 2000-luvulla. - Virittäjä 122 s. 224-254. https://doi.org/10.23982/vir.66881.

— 2019: Vepsän kielen merkityksestä puhujilleen. - Virittäjä 123 (2), verkkoliite. https://doi.org/10.23982/vir.79846.

RAHKONEN, PAULI 2011: Tampere - saamelainen koskiappellatiivi. - Virittäjä 115 s. 252 256.

RAMStedT, G. J. 1900: Tsagan sara, mongolilainen juhla. - Virittäjä 4 s. 38-40.

RAVILA, PAAVO 1933a: Pari mordvalaista johdinta. - Virittäjä 37 s. 350-354. 
1933b: Suomalais-ugrilainen Seura 1883-1933. - Suomalais-Ugrilaisen Seuran Aikakauskirja XLVI,1.

— 1935: Konrad Nielsen 60-vuotias. - Virittäjä 39 s. 391-393.

— 1938: Numerusprobleemeja. - Virittäjä s. 286-297.

_ 1943: Uralilaisen lauseen alkuperäisestä rakenteesta. - Virittäjä 47 s. 247-263.

— 1945: Suomalais-ugrilaisten kielten taivutuksen historiaa. - Virittäjä 49 s. 314-326.

— 1949: Suomalais-ugrilaiset kielet ja yleinen kielitiede. - Virittäjä 53 s. 1-6.

— 1951: Totuus ja metodi kielitieteessä. - Virittäjä 55 s. 113-122.

— 1953: Sanaluokat, erityisesti uralilaisia kieliä silmällä pitäen. - Virittäjä 57 s. 41-50.

— 1957: Suomalais-ugrilaisten kielten tempusvartaloiden muodostumisesta. - Virittäjä 61

s. $173-180$.

— 1958: Yrjö Henrik Toivonen. Muistopuhe, pitänyt 8.3.1957 Paavo Ravila. -

Suomalainen Tiedeakatemia. Esitelmät ja pöytäkirjat 1957 s. 53-61. Helsinki.

_ 1960: Nominaalilause ja finiittimuodot. - Virittäjä 64 s. 245-250.

SALMINEN, TAPANI 2014: Suomalais-samojedilaisia muotovertailuja. - Nobufumi Inaba, Jorma Luutonen, Arja Hamari \& Elina Ahola (toim.), Juuret marin murteissa, latvus yltää Uraliin. Juhlakirja Sirkka Saarisen 60-vuotispäiväksi 21.12.2014 s. 291-302. SuomalaisUgrilaisen Seuran Toimituksia 270. Helsinki: Suomalais-Ugrilainen Seura.

Salminen, Timo 2008: Aatteen tiede. Suomalais-Ugrilainen Seura 1883-2008. Helsinki:

Suomalaisen Kirjallisuuden Seura.

SARIVAARA, ERIKA 2012: Statuksettomat saamelaiset. Paikantumisia saamelaisuuden rajoilla. - Virittäjä 116 (3), verkkoliite. https://journal.fi/virittaja/article/view/7309

SETÄLÄ, E. N. 1929: Suomalais-Ugrilainen Seura 40-vuotias. Esitelmä Suomalais-Ugrilaisen Seuran vuosikokouksessa 2.12.1923. - Suomalais-Ugrilaisen Seuran Aikakauskirja 43 s. 120-132.

SPETS, SiLJA-MAIJA 2021: Marin kielten menneen ajan tempusten evidentiaalisuudesta ja modaalisuudesta. - Virittäjä 125 s. 248-257. https://doi.org/10.23982/vir.103170

TIRKKONEN, JANI-MATTI 2012: ’Lopullinen totuus pohjoiseurooppalaisten alkuperästä”? Kalevi Wiik vallankumouksellisen paradigman edustajana juuret-kiistassa. Pro gradu tutkielma. Itä-Suomen yliopisto. http://urn.fi/urn:nbn:fi:uef-20120723.

TOIVONEN, Y. H. 1934: Suomalais-ugrilaisesta kielentutkimuksesta ja sen lähimmistä tehtävistä. - Virittäjä s. 379-391.

1953: Suomalais-ugrilaisesta alkukodista. - Virittäjä 57 s. 5-35. 
TUNKELO, E. A. 1902: Elias Lönnrot Suomen lappalaisten äidinkielen puolesta. - Virittäjä 6 s. $49-61$.

TURUNEN, RIGINA 2010: Katoavaa monimuotoisuutta tallentamassa. - Virittäjä 114 (3), verkkoliite. https://journal.fi/virittaja/article/view/4351

Virittäjä 1897: Lukijalle. - Virittäjä 1 s. 1-3. 